\title{
Effect of Leadership Management on Students' Satisfaction in ISO 9001: 2008 Certified Universities in Kenya
}

\author{
Hilary Kipchirchir Kandie ${ }^{1^{*}}$, Wario Guyo (PhD) ${ }^{2}$, Thomas A. Senaji (PhD) ${ }^{3}$ \\ ${ }^{1}$ Department of Business Administration, School of Business, College of Human Resource and Development, \\ Jomo Kenyatta University of Agriculture and Technology, Kenya \\ ${ }^{2}$ Director and Senior Lecturer, Nairobi CBD Campus, Jomo Kenyatta University of Agriculture and Technology, \\ Kenya \\ ${ }^{3}$ Kenya Methodist University, Kenya
}

*Corresponding Author: Hilary Kipchirchir Kandie, Department of Business Administration, School of Business, College of Human Resource and Development, Jomo Kenyatta University of Agriculture and Technology, Kenya

\begin{abstract}
In the present competitive business environment, quality of products and/service offered by any organization play an important role in determining the satisfaction of the customer. Customer satisfaction on the other hand contributes to firm performance. Similar to other organizations, universities endeavor to ensure quality of their service is attractive to the customers. To enhance the confidence in the quality of teaching, learning and research, most Universities in Kenya choose to be certified on ISO 9001 quality management standard. The Standard requires the organizations to establish a quality management system $(Q M S)$ to ensure provision of quality services and products that satisfy the customers. Since quality of university education has been a subject of concern in Kenya, there is need to understand what action is being taken to address the quality concerns. It is against this background that the study sought to establish the role of Leadership management based on ISO 9001 standard on the students' satisfaction in ISO 9001:2008 certified universities in Kenya. A sample of 384 students drawn from all the 24 certified universities participated in the study. Data was collected using questionnaires. Quantitative data analysis methods used to generate frequency distribution, descriptive and inferential statistics. Specifically, ordered probit regression model was used to analyse the data using STATA software whereas chi squire test was used to test the hypotheses related to students' satisfaction. The findings established that Leadership management enhanced the students' satisfaction among the ISO 9001 certified universities in Kenya. The inferential statistics analysis revealed that leadership management was positively and significantly related to students' satisfaction. It is concluded that ISO 9001 certified universities in Kenya had better students' satisfaction as a result of leadership management. Based on the findings it is recommended that the universities should embrace better strategies to enhance the satisfaction of the students through resource management, a better effective leadership management, enhance product realisation and cultivate a culture of improvement management of the Quality Management Systems (QMS).
\end{abstract}

Keywords: Leadership Management, Students' satisfaction, ISO certification, and Universities in Kenya

\section{INTRODUCTION}

\subsection{Background of the Study}

In Africa, the university demand-supply scene is even more precarious. The global growth of enrolments in university education can be explained by the emergence of a private tertiary education sector. While public universities have continued to grow, the number of private universities has exploded (Wanzala, 2013). The World Bank notes that private university education has become the fastest growing segment of university education worldwide (World Bank, 2009; Clothey, 2011; McCowan, 2008; Waweru, 2013). University education plays an important role in the development of the knowledge based economy in a highly competitive and rapidly changing global environment (Ojiambo, 2009) consequently Kenya's university education system must be focused, efficient and able to create knowledge and deliver relevant and quality learning to sustain a knowledge economy that is internationally competitive (MOE, 2012) and satisfactory to the students/learners and stakeholders in the society. 


\subsubsection{Quality Management System}

According to Manders, (2014) ISO 9001 sets out the requirements for a quality management (QMS) system where an organization can demonstrate its capability to deliver quality products and services that fulfil customer and regulatory requirements. It is designed to help organizations ensure that they meet the needs of customers and other stakeholders (Lushi, Mane, Kapaj \& Keco, 2016). In this regard 32 universities have implemented QMS based ISO 9001 standard. ISO 9001, the leading standard on quality management, A total of 1,033,936 certificates were issued to ISO 9001 in 2015 (including 4190 issued to the 2015version published in September 2015) which is a slight decrease of $0.2 \%$ on 2014 (ISO, 2016).ISO 9001 standard stipulates the requirements for quality management systems(Kaziliunas, 2010).

\subsubsection{University Education in Kenya}

Kenya's future as a prosperous and internationally competitive nation based on realisation of vision 2030 strategy will depend on university education system (Wafula, 2013;Wanzala, 2013). Growth has been witnessed in the university sub-sector with growth in enrolment for the period 2010/11-2015/16. The Commission of University Education (CUE) is established under Universities Education Act, 2012 (CUE, 2016) and charged with the responsibilities to accredit universities; regulate university education; promote and oversee the development of quality and relevant university education through accreditation, regular inspections, monitoring and evaluations; collection, dissemination and maintenance of data and promotion of quality education, research and innovations (MOE, 2012; CUE, 2016). There are 70 universities in Kenya, 33 of which are public including constituent colleges and 37 private including constituent colleges with a total of 168 campus spread across the 47 counties in Kenya (CUE, 2016).The three categories of status of University campuses/constituent colleges are: Accredited campuses/constituent colleges, Adopted campuses/constituent Colleges and campuses/constituent colleges under Review.

\subsubsection{ISO 9001 standard in the University Education System}

Many public and private universities in Kenya are ISO 9001 certified by various certification bodies present in Kenya (Kimani \& Okibo, 2013). Upon award of ISO 9001 it is a requirement that the organisation maintains the quality management system through internal audits, management review, quality policy, quality objective, preventative and corrective action for continual improvement (Lazibat, Sutic \& Jurcevic, 2009) while the certification body regularly performs surveillance audits to check the maintenance of the quality management system by the organisation (Guchu \& Mwanaongoro, 2012).

Quality of university education and the need for effective quality assurance mechanisms beyond those of institutions themselves are becoming priority themes in national strategies for universities (MOE, 2012).

\subsection{Statement of the Problem}

Universities just like any other business need to understand the perception of the students (customers) regarding the services offered (Naidoo, 2011). According to Helgesen and Nesset (2007), Purgailis and Zaksa (2012), Sultan (2013), Yusoff and Woodruffe-Burton (2015) students' satisfaction is an outcome of quality service which is driven by quality management system established by the university. To enhance the quality of services offered in universities and heighten students' satisfaction, it is essential to adopt QMS based on ISO 9001 standard (Sarbu, Ilie, Enache \& Dumitriu, 2009). However, despite the merit that surrounds QMS and ISO 9001 standard; there has been growing concern on its influence on the customer satisfaction (Lazibat, Sutic, \& Jurcevic, 2009; and Mabururu, 2011).

Empirical studies on implementation of quality management systems have brought a conflicting debate between QMS based on ISO 9001 and customer satisfaction. For instance,Becket and Brookes (2006); Papadimitriou and Westerheijden (2010); and Lushi et al. (2016) established that implementation of the QMS such as the ISO 9001 played a key role in enhancing quality of services and/or products offered by the organizations thus promoting satisfaction among the customers. On the other hand, Mehralizadeh and Safaeemoghaddam, (2010); and Vusa (2016) contended that customer satisfaction was mainly determined by the customer service and ability of the organizations to meet 
their needs but not through implementation of some QMS based on ISO 9001. This explicitly shows the need for a study to clear the doubt on the roles of QMS based on ISO 9001 on customer satisfaction.

The studies on influence of QMS on students' satisfaction were conducted in more than a decade ago where much has changed since then in relation to service and/or product quality and the strategies of quality management as well (Faganel \& Macur, 2005; Poksinska, Kahlgaard \& Antoni, 2002; and Sakthivel, Rajendran \& Raju, 2005). Locally, the studies on QMS and satisfaction focused on other industries such as state corporations and NGOs unlike the current study that focused on educational sector which is a major sector as far as country's development and growth is concerned.

Mekic and Goksu (2014) and Lushi, Mane, Kapaj and Keco (2016) in their studies on influence of QMS implementation and customer satisfaction used regression model to carry out the analysis. The current study adopted a different model, the ordered Probit model which according to O'Connell (2006) fulfills the requirements for both discrete and ordinal outcomes. Majority of the previous studies were carried out in developed countries such as Canada and UK where the systems and organizational management strategies are more diverse unlike the current study which was carried out in Kenya which is a developing country.

Based on the gaps reviewed, the current study was therefore deemed appropriate to examine the relationship between ISO 9001 Quality Management System implementation and students' satisfaction. Specifically, the influence of leadership management on students' satisfaction in ISO 9001 certified universities in Kenya

\subsection{Objective of the Study}

The main aim of this study was to determine the role of leadership management implementation on Students' satisfaction in ISO 9001:2008 certified universities in Kenya

\section{LITERATURE REVIEW}

\subsection{Theoretical Review}

\subsubsection{Quality Management Systems}

Quality management $(\mathrm{QM})$ is a set of opinions and ideas for improving the quality of products or services, which widely called "management philosophy" (Al-Ibrahim, 2014). Its main aims are to satisfy customers and survive in the market (Neyestani and Juanzon, 2016). Without doubt, quality experts (gurus) had the significant roles to expend and transform the concept of quality from a mere technical system to a broader body of knowledge known as total quality with management implications in production (Maguad, 2006).

\section{a) Quality Gurus}

Historically, QM was first emerged by the contributions of quality gurus, such as Deming and Juran in Japan after Second World War. Then Crosby, Feigenbaum, Ishikawa, and others had developed this powerful management technique for improving business quality within the organizations. During the period 1980s to 1990s, many national and international quality awards (QAs) have been established to provide guidelines for implementing TQM based on the suggestions and theories of QM gurus (Neyestani and Juanzon, 2016). The gurus extensively made substantial contribution to quality management by their theories in improving quality. QM techniques and tools could be innovated by these theories (Alamri, Alharthi, Alharthi, Alhabashi, \& Hasan, 2014).

Feigenbaum was the first guru, who defined "Total Quality Control" as an effective system for integrating the quality-development, quality-maintenance, and quality-improvement efforts of the various groups in an organization to enable marketing, engineering, production and service at the most economical levels which allows for full customer satisfaction (Feigenbaum, 1991). Kaoru Ishikawa is considered by many researchers to be the founder and first promoter of the 'Fishbone' diagram (or Cause-and-Effect Diagram) for root cause analysis and the concept of Quality Control (QC) circles (Ishikawa, 1985). These theorists are regarded as the key founders of TQM philosophy, and the origin of QM concept evolves mostly from their work. 


\section{b) Quality Management Principles}

Customer Focus Principle; This is the notion common to all quality processes that quality consists of meeting and exceeding the expectations of customers Cianfrani \& West, 2009; Dissanayake, 2011; Kumar \& Balakrishnan, 2011; Karani \& Bichanga, 2012; and Taib, Warokka, \& Hilman, 2012). In the educational context the customers could be the students, their parents, their future employers or other educational establishments.

Leadership principle;a leader's ability to establish a vision and purpose is the key to a successful organization. Leaders inspire others, provide them with the resources to do their job, and ensure that the needs of all parties, staff, customers, the local communities and others are identified and met (Cianfrani \& West, 2009; Dissanayake, 2011; Kumar \& Balakrishnan, 2011; Karani \& Bichanga, 2012; and Taib, Warokka, \& Hilman, 2012). Leadership has been shown to be the key variable in successful Universities.

Involvement of People Principle; Organizations need their people to use their abilities for the benefit of the organization (Cianfrani \& West, 2009; Dissanayake, 2011; Kumar \&Balakrishnan, 2011; Karani \& Bichanga, 2012; and Taib, Warokka, \& Hilman, 2012). Ensuring that this happens is important for innovation and creativity.

Process Approach Principle; this is about the efficiency and effectiveness of the organization's core activities and the importance of developing a systematic approach to their management (Cianfrani \& West, 2009; Dissanayake, 2011; Kumar \& Balakrishnan, 2011; Karani \& Bichanga, 2012; and Taib, Warokka, \& Hilman, 2012).

System Approach to Management Principle; this is about recognizing the interrelatedness of processes and aligning them to achieve the best results Cianfrani \& West, 2009; Dissanayake, 2011; Kumar \& Balakrishnan, 2011; Karani \& Bichanga, 2012; and Taib, Warokka, \& Hilman, 2012). It is about ensuring that there are clear systems in place and establishing clear targets and goals. Continual Improvement Principle; Continuous improvement is the objective of all quality systems. It is about ensuring that people have the training and skills required to make improvements and ensures that there is an organization-wide approach to the improvement of performance (Cianfrani \& West, 2009; Dissanayake, 2011; Kumar \& Balakrishnan, 2011; Karani \& Bichanga, 2012; and Taib, Warokka, \& Hilman, 2012).

Mutual Beneficial Supplier Relationship Principle; any organization is in a mutually beneficial partnership with its suppliers that can create value for both parties (Cianfrani \& West, 2009; Dissanayake, 2011; Kumar \& Balakrishnan, 2011; Karani \& Bichanga, 2012; and Taib, Warokka, \& Hilman, 2012).

\section{c) Customer Satisfaction}

Customer satisfaction is a term frequently used in marketing. It is a measure of how products and services supplied by a company meet or surpass customer expectation. Customer satisfaction is defined as "the number of customers, or percentage of total customers, whose reported experience with a firm, its products, or its services (ratings) exceeds specified satisfaction goals (Farris, Neil, Phillip \& David, 2010).

According to Alipoor, Nejad and Sabzikara (2017), the concept of customer satisfaction has attracted much attention in recent years. Organizations that try to analyze this concept should begin with an understanding of various customer satisfaction models. Such models clarify various theories about customer satisfaction, making research and analysis in this topic more focused and less wasteful of research resources.

In literature antecedents of satisfaction are studied from different aspects. The considerations extend from psychological to physical and from normative to positive aspects. However, in most of the cases the consideration is focused on two basic constructs as customers' expectations prior to purchase or use of a product and his relative perception of the performance of that product after using it(Mundhe, 2014). 


\subsubsection{Quality Management Models}

\section{a) Hersey-Blanchard Situational Leadership Model}

According to Safari and Sabouri (2014), the situational leadership model is a leadership theory developed by Paul Hersey and Kenneth Blanchard. The Hersey-Blanchard Situational Leadership Model rests on two fundamental concepts; leadership style and the individual or group's maturity.

The situational leadership model views leaders as varying their emphasis on task and relationship behaviours to best deal with different levels of follower maturity (Boyce, 2006). Managers using the situational leadership model must be able to implement the alternative leadership styles as needed. A manager's style is determined by the situation, the needs and personalities of his or her employees (Nadeem, 2012).

There are different management styles available which are utilized by educational managers both in office as well as in the field work to achieve the set targets aimed at enhancing personal and collective efficiency of the employees on one hand and the students on the other in the organisation. In the prevailing educational scenario appropriate management style could determine the possible improvement of the concerned personnel and the organisation (Nadeem, 2012), hence students satisfaction.

An academic leader is one who has broader vision of his field and has power to bring the change (Mehmood, Khan, Raziq, \& Tahirkheli, 2012) and drive QMS to enhance the quality of education and students' satisfaction which is a priority for the success of any business. In the university, the big name in terms of quality education and students' satisfaction depends on the academic leaders. Academic leaders' work style, level of acceptability and the will to change are most important factors which set the quality of education and students' satisfaction of the universities. In the current era of knowledge based economy there is pressure on universities to ensure that the graduates meet with the demands of industry and society. For all of this to be achieved the most important thing is leadership. The success of the organization in achieving quality depends on the ability and attitude of the top management (Serafimovska \& Ristova, 2011).

\section{b) Total Quality Management (TQM) Model}

Fundamentally, TQM Model embraces the principle that organisations should listen to those whom they serve, continually evaluate how well they are responding to the needs of their constituencies, and initiate change in order to meet or exceed the expectations of these groups (Lazibat, Sutic \& Jurcevic, 2009).TQM Model focuses on processes and tools that extract quality definitions from costumers and translate their desires into corporate actions (Safakli \& San, 2007).

Leadership serves as a prime in this model and must be transmitted through all the principles and core concepts in order to achieve business excellence. Core concepts represent those managerial areas that must be given special and continual attention to ensure high performance. These factors are critical because only if they are executed properly then the organisation will achieve business excellence. These factors are useful because they can be used by managers and leaders for missions, policies and decision making (Kanji et al., 1999).

TQM Model was initially used for the measurement of quality in the University sector in 1993 (Clayton, 1993).Total Quality Management (TQM) Model, aiming at customers' satisfaction to the higher education area was also quite widespread. TQM Model can be considered as the first qualitymanagement model in higher education that caused a lot of discussions about potential relevance for the sector, as well as its educational and social implications (Stensaker, 2007). Quality cannot be enforced from outside the university and can only be achieved through the join commitment and effort of all those inside it (Lazibat, Sutic \& Jurcevic 2009). According to Elton (1993) TQM Model in Universities should be established at all levels of each university to increasing recognition and resourcing of teaching and rewards for excellence.

\section{c) EFQM Model}

In 1998 the EFQM (European Foundation for Quality Management) Excellence Model was established by 14 European large companies (Hides, et al., 2004) and was initially developed as a model to underpin the European Quality Award, called European Model for Business Excellence. 
Excellent leaders develop and facilitate the achievement of the mission and vision, develop values required for long term success and implement these via appropriate actions and behaviors, and are personally involved in ensuring that the University's management system is developed and implemented (Oakland, 2003).

The adaptation of EFQM Excellence Model for higher education has commenced since the establishment of the business version of the model. Most European universities have implemented EFQM as the basis for the measurement of their activities (Steed, 2002; Tari, 2006; Boele, 2008; Spasos, at al., 2008; Lazibat, Sutic \& Jurcevic, 2009). It has been successfully been used by several universities across Europe and Asia (Chua, 2004 and Spasos et al., 2008). The excellence in the higher education in the EFQM Model is not limited to traditional measure of profit/loss but encompasses the areas such as leadership, people management and satisfaction (Arjomandi, Kestell \& Grimshaw, 2009).

The EFQM focuses on mission definition, leadership and the processes which are shared between the core activities of higher education. Conversely, the core activities of the universities are all intertwined and so the implementation of such policies and methods will guarantee the quality in all aspects of its activities (Hides et al., 2004).

\subsection{Conceptual Framework}

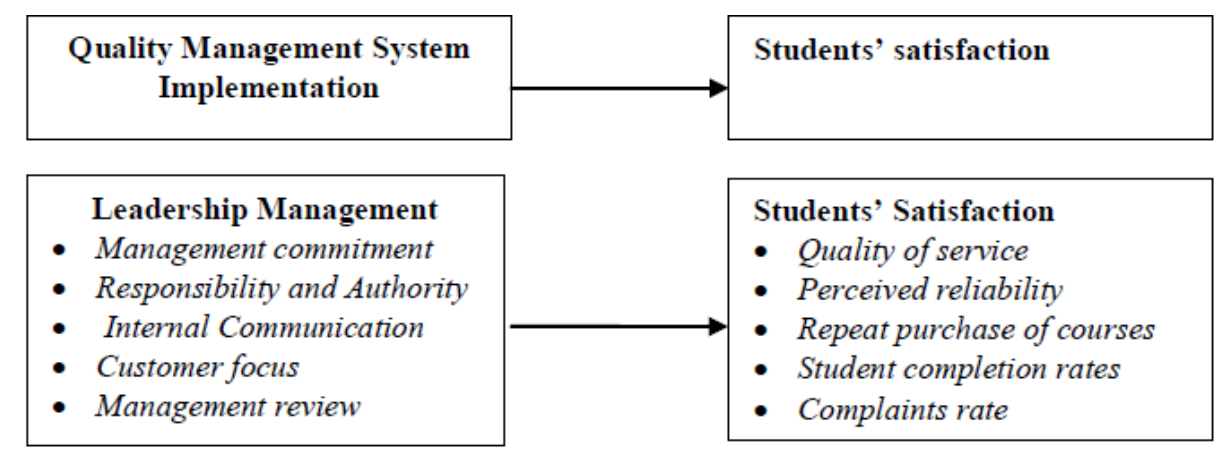

Figure1. Conceptual Framework

\subsubsection{Leadership Management}

Leadership and management are often considered practically overlapping concepts. Leadership is a process by which a person influences others to accomplish an objective and directs the organization in a way that makes it more cohesive and coherent (Sharma \& Jain, 2013). This definition is similar to Northouse's (2007) who defined leadership as a process whereby an individual influences a group of individuals to achieve a common goal. Leaders carry out this process by applying their leadership knowledge and skills. On the other hand, management is defined as a process that is used to accomplish organizational goals, that is, a process that is used to achieve what an organization wants to achieve (Bohoris \& Vorria, 2007). A well balanced organization should have a mix of leaders and managers to succeed, and in fact what they really need is a few great leaders and many first-class managers (Kotterman, 2006).

The entire clause five of ISO 9001:2008 is management's responsibility and dedicated to leadership, top management and strategic planning processes of the organisation rather than to specific products (Hoyle, 2009). In management responsibility, leaders are the main players in the way to culture organization quality management (ISO, 2015). QMS is a process that begins with a vision which is actively promoted by the leaders by considering the needs of all interested parties including customers, owners, employees, suppliers, financiers, local communities and society as a whole(Misztal, 2013). Its achievement requires effective leadership that is in a position to build a healthy organizational culture that will transform into QMS (Serafimovska \& Ristova, 2011). According to Miller (2007) leadership evaluation are measured through their order and support towards organization mission, vision, strategic planning and organizational structure which includes quality initiatives to improve quality of products and service, and customer satisfaction.

Top management commitment plays a vital role in the implementation of the quality management system (Tari, 2005).Most quality gurus put much focus on top management commitment in their 
respective theories (Yousaf, 2006). QMS process should be aligned with management strategic business so that it can assure top management commitment. The current approach to quality management system is based on principles that are specified on the basis of experience and good practices and approaches ofmajor leaders in the field of quality management (Paulová \& Míkva, 2011). Eight QMS principles creates the backbone of the implementation of QMS by the leadership and are incorporated in the standard of ISO 9000:2005(Paulová \& Míkva, 2011) and the first principle is leadership. This variable is anchored on Hersey-Blanchard Situational Leadership Model, Total Quality Management (TQM) Model, EFQM Model, Strategic Management Model and 5P's Mode and therefore, the relationship is formally stated in its alternative form as follows:

$\boldsymbol{H}_{1}$ :Leadership Management has positive significant influences on the students' satisfaction in ISO 9001: 2008 certified Universities in Kenya.

\subsubsection{Students' Satisfaction}

In a University, students are the main customer of the organization (Hill, 1995; Sakthivel et al., 2005; Zairi, 1995; IWA, 2007) therefore students' satisfaction should always be considered by the university when measuring the quality of education. Assessing students' satisfaction, achievement and absorption capacity are critical not only for the students and their institutions but also for the business industry who are potential recruiters of these students (El-Hilali, Al-Jaber, \& Hussein, 2015).

According to Pitman (2014), quality of university education is therefore defined hierarchically as one that: (i) supplied students and the market with in-demand skills (fitness for purpose), (ii) retained and graduated a high proportion of students (efficiency); and (iii) generated positive student feedback (customer satisfaction).

According Kwek, Lau and Tan (2010), there are two approaches adopted by researchers in establishing the level of students' satisfaction in universities. Students' satisfaction can be evaluated based on the perspective of the students ('outside-in' approach) or the perspective of the academicians and administrators ('inside-out'approach) (Hoffman \& Bateson, 2006). This variable is anchored on the Kano Model, Satisfaction Model, The Scheerens Model, Creemers' Model and, Heneveld and Craig Model discussed

\subsection{The Empirical Review}

In the study of 15 universities in the Albanian higher education system (Brucaj, 2014) where 127 participants were surveyed to establish factors that contribute to institutional quality of education and effective leadership strategies that have been used to promote a high quality education. The findings point out the importance of providing strategic direction to university staff in order to realize the mission and promoting academic excellence by the management and leadership. Similarly, the findings show that to increase the quality standards in universities it is essential for leadership management to adopt certain leadership strategies to implement quality management philosophy and practices in the educational system.

Brucaj (2014) concluded that in order to be competitive, successful and achieve quality education in the market the management and leadership need to rethink their strategies and open to new leadership management strategies. Those strategies will contribute to enhance quality of education in the university. Therefore the role of leadership management is very important in designing and implementing the most appropriate strategies for their institutions to enhance quality of education and students' satisfaction.

\subsection{Research Gaps}

Although Tam and Cheng (1996) argue that resource-input model of education service quality can be adopted by the administrators of universities to evaluate perceived service quality and students' satisfaction, there is a lack of empirical testing in the existing literature to support this contention which is a gap in the literature and will be further explored in the current research.The researcher agrees with Pratasavitskaya and Stensaker (2010) that the analysis of models and approaches of quality management at the University level has been rare address in the literature, which is considered by (Rosa, Sarrico \& Amaral, 2012) as an unfortunate situation. 
The existing literature has showed that research has been done on TQM practices in Kenya higher education, Factors affecting TQM Processes in State Corporation on Customer Satisfaction, and TQM practices in Kenyan secondary schools. Little or no empirical research has been conducted dealing with ISO 9001 Model and their effects on overall business performance and Quality of Services or Education in Kenya. In order to bridge this gap, an investigation into the effects of ISO 9001 Certification on students' satisfaction in Kenya in Universities is needed.

\section{RESEARCH METHODOLOGY}

\subsection{Research Design}

This study adopted a cross-sectional survey research design to examine the effect of QMS implementation based on ISO 9001 on students' satisfaction in the universities. Cross-sectional survey entails the collection of data on more than one case and at a single point in time in order to collect a large amount of quantifiable data in connection with two or more variables which are then examined to detect patterns of association (Azarian, 2011).

\subsection{Population of the Study}

According to CUE (2016) there are 70 universities in Kenya, 33 of which are public and 37 private that have been authorized by the Commission forUniversity Education to offer university degrees either by being awarded charters, letters ofinterim authority, or letters of registration as at October, 2016. The target population was 70 universities which were either private or public universities ISO 9001: 2008 Certified in Kenya.

The population of study was all the ISO 9001: 2008 certified universities authorised to operate in Kenya as at October, 2016 which was 24 universities. The researcher was interested in finding out how the students are satisfied with the education service provided by the universities which were ISO 9001 certified based on the established Quality Management system.

\subsection{Sample and Sampling Technique}

The researcher obtained the list of accredited universities from the Commission of University Education website as the sampling frame then compile a list of ISO 9001 Certified and Non-ISO 9001 Certified Universities by getting the status from each university through the Quality Management representatives or University Administration. Target population of the ISO 9001 certified universities was 24 as at December 2016, hence no point to sample the population since this was a small population. The researcher conducted a census survey to collect data.

The research used non-probability sampling technique to select the respondents for the study. Ilker, Sulaiman, and Rukayya (2016) stated that non-probability sampling technique is useful when choosing sample when randomisation is impossible like when the population is very large and the resources, time and workforce is limited. The researcher used non-probability convenience sampling technique to select the potential students' respondents because of the proximity and accessibility of the respondents.

\subsection{Research Instruments}

Keeping in view the nature of the problem and population, questionnaires which contain structured questions with Likert-type scale was used to collect data. According to Sekaran and Bougie (2010) questionnaires can be administered personally, mailed to the respondents, or electronically distributed. Moreover, they have the advantages of covering a wide geographical area in the survey and the ease with which the respondents can complete the questionnaires in their homes at their own pace.

\subsection{Data Collection Method}

The study collected primary data from the respondents identified in the research. For this study to collect primary data, questionnaire was used. Each questionnaire was accompanied by a cover letter providing explanations and assurances that all individual responses were treated with confidentially.

\subsection{Data analysis and Presentation}

In this research the response categories are inherently ordered. The dependent variable was discrete as well as ordinal. Under these circumstances, conventional regression analysis is not appropriate 
(Green, 2012). Instead, the ordered probit model is used to estimate models where the dependent variable associated with more than two outcomes is discrete and ordered(Long \& Freese, 2014) and to address the requirement of ordinality as well as the requirement of discreteness, the researcher will use an ordered probit model in the study. O'Connell (2006) stated that ordered probit model fulfils both the requirements as it is suitable for producing probability estimates for outcomes that are discrete and ordinal

\section{FINDINGS}

\subsection{Response rate}

The study sought to find out the rate at which the targeted respondents participated in the study. This would therefore help to determine whether the study attained a reliable number of respondents to make conclusions and recommendations. The study had a sample of 384 respondents who were surveyed using a structured questionnaire from the 24 universities that were ISO 9001 certified as at December 2016 as shown in table 4.1. A response rate 70\% (269 respondents) was achieved and the data used for the analysis. This therefore makes the study appropriate to make conclusions and recommendations since according to Creswell (2005) and Kingslay (2012) a response rate of 30-60\% in a study is adequate for making conclusions and recommendations

Table1. Response Rate

\begin{tabular}{|l|l|l|}
\hline Response Rate & Frequency & Percentage \\
\hline Responses & 269 & 70 \\
\hline Non-Response & 115 & 30 \\
\hline Total Sample size & $\mathbf{3 8 4}$ & $\mathbf{1 0 0 . 0}$ \\
\hline
\end{tabular}

These represents a response rate of $70 \%$ was therefore considered appropriate to derive the inferences regarding the objectives of the research and analysis. This therefore makes the study worth to make conclusions and recommendations since according to Creswell (2005) and Kingslay (2012) a response rate of $30-60 \%$ in a study is adequate for making conclusions and recommendations which agrees with Mugenda (2008) that 50\% response rate is adequate, $60 \%$ good and above 70 percent rated very well for any study.

\subsection{Leadership Management}

In the study, leadership management was operationalised into; Management commitment; Responsibility and Authority; Internal Communication; Customer focus and Management review. A five -point scale was used to measure each of the sub-variable and the results were presented in tables.

\subsubsection{Reliability Analysis}

A reliability test analysis for the research instrument on the variable leadership management was carried out as presented in the table. A first test and a retest were carried out.

Item-total Statistics

\begin{tabular}{|l|l|l|l|l|}
\hline & $\begin{array}{l}\text { Scale Mean } \\
\text { If Item Deleted }\end{array}$ & $\begin{array}{l}\text { Scale Variance } \\
\text { If Item Deleted }\end{array}$ & $\begin{array}{l}\text { Corrected Item } \\
\text { Total Correlation }\end{array}$ & $\begin{array}{l}\text { Alpha } \\
\text { If Item Deleted }\end{array}$ \\
\hline VAR00019 & 19.8636 & 23.1965 & .5475 & .7873 \\
\hline VAR00020 & 20.3030 & 23.1991 & .5831 & .7812 \\
\hline VAR00021 & 20.4242 & 21.7557 & .6370 & .7704 \\
\hline VAR00023 & 19.6667 & 24.7179 & .4450 & .8042 \\
\hline VAR00024 & 19.7576 & 23.3557 & .5363 & .7893 \\
\hline VAR00026 & 19.7879 & 23.3697 & .5923 & .7800 \\
\hline VAR00027 & 19.6515 & 24.1075 & .4984 & .7956 \\
\hline
\end{tabular}

\section{Reliability Coefficients}

$N$ of Items $=7$

Alpha $=0.8119$

On 'Leadership Management' Likert's questions, the alpha coefficient for the seven items was 0.8119 , suggesting that the items had relatively high internal consistency. A retest of the reliability 
was carried out. The retest as shown in Table 4.6 revealed that the new Cronbach's alpha was 0.8971 which implies that the reliability became stronger after the retest of the instrument.

Table2. Cronbach's Alpha on Leadership Management

\begin{tabular}{|l|l|l|l|l|}
\hline Variable & \multicolumn{2}{|c|}{ Test } & \multicolumn{2}{c|}{ Retest } \\
\hline $\begin{array}{l}\text { Leadership } \\
\text { Management }\end{array}$ & Cronbach's Alpha & Number of items & Cronbach's Alpha & Number of Items \\
\cline { 2 - 5 } & 0.8119 & 7 & 0.8971 & 7 \\
\hline
\end{tabular}

\subsubsection{Validity Test}

Validity test was carried out in the study on the variable; leadership management. For content validity to be ensured in this variable, the researcher applied expert judgement of the supervisors on the items contained in the questionnaire on the variable; leadership management. The supervisors counterchecked and confirmed the accuracy of the concepts being measured.

\subsubsection{Descriptive Analysis}

The second objective of the study was to establish the influence of QMS leadership on the students' satisfaction in ISO 9001 certified universities in Kenya. The study sought to establish the opinions of the respondents regarding specific statement on leadership and satisfaction with the services offered at the institutions. As the findings in Table 4.7 below shows, a small majority (39.3\%) of the respondents were satisfied with the first statement that university management is committed to provide the resources for the education service. Specifically, $10.9 \%$ of the total respondents were very dissatisfied with the statement, $15.1 \%$ were dissatisfied with the statement, $19.9 \%$ were uncertain, and $14.8 \%$ of the total respondents were very satisfied with the statement. The second statement was that the students' views are sought in order to enhance the satisfaction where $16.4 \%$ were very dissatisfied with the statement, $18.5 \%$ were dissatisfied, $18.2 \%$ were uncertain, $29.7 \%$ were satisfied and $17.2 \%$ were very satisfied. The other statement was that survey is conducted to identify the needs of the students in order to enhance the satisfaction where $20.1 \%$ of the respondents were very dissatisfied with the statement, $18.0 \%$ were dissatisfied, $15.4 \%$ were uncertain, $31.0 \%$ were satisfied and $15.6 \%$ of the total respondents were very satisfied.

The respondents' opinion was further sought on the statement that the students provide feedback on the teaching and courses provided whereby $7.6 \%$ of the respondents indicated that they were very dissatisfied with the statement, $12.8 \%$ indicated that they were dissatisfied, $15.4 \%$ were uncertain, $39.3 \%$ were satisfied and $25.0 \%$ were very satisfied. The other statement was that the staff and administration are easily available to the students. In this, $8.9 \%$ of the respondents were very dissatisfied, $14.3 \%$ were dissatisfied, $13.3 \%$ were uncertain, $40.6 \%$ were satisfied and $22.9 \%$ of the total respondents indicated that they were very satisfied with the statement. On the statement that the students are fully informed of their responsibilities, 5.5\% of the respondents said that they were very dissatisfied, $9.6 \%$ were dissatisfied, and $14.6 \%$ said they were uncertain, $45.8 \%$ were satisfied and $24.5 \%$ of the total respondents indicated that they were very satisfied with the statement. Lastly, the respondents' opinion was sought on the statement that the details regarding the location and availability of all learning and physical resources are communicated to students. In this statement, $7.3 \%$ of the respondents indicated that they were very dissatisfied with the statement, $8.9 \%$ said that they were dissatisfied with the statement, $13.8 \%$ were uncertain, $44.3 \%$ were satisfied and $25.8 \%$ of the total respondents said that they were very satisfied with the statement.

Table3. Degree of satisfaction with statements on Leadership Management

\begin{tabular}{|l|l|l|l|l|l|l|}
\hline Statement & $\begin{array}{l}\text { Very } \\
\text { dissatisfied }\end{array}$ & Dissatisfied & Uncertain & Satisfied & $\begin{array}{l}\text { Very } \\
\text { satisfied }\end{array}$ & Total \\
\hline $\begin{array}{l}\text { University management is } \\
\text { committed to provide the } \\
\text { resources for the education } \\
\text { service }\end{array}$ & 10.9 & 15.1 & 19.8 & 39.3 & 14.8 & 100.0 \\
\hline $\begin{array}{l}\text { The students views are } \\
\text { sought in order to enhance } \\
\text { the satisfaction }\end{array}$ & 16.4 & 18.5 & 18.2 & 29.7 & 17.2 & 100.0 \\
\hline $\begin{array}{l}\text { Survey is conducted to } \\
\text { identify the needs of the }\end{array}$ & 20.1 & 18.0 & 15.4 & 31.0 & 15.6 & 100.0 \\
\hline
\end{tabular}


Effect of Leadership Management on Students' Satisfaction in ISO 9001: 2008 Certified Universities in Kenya

\begin{tabular}{|l|l|l|l|l|l|l|}
\hline $\begin{array}{l}\text { students in order to } \\
\text { enhance the satisfaction }\end{array}$ & & & & & & \\
\hline $\begin{array}{l}\text { The students provide } \\
\text { feedback on the teaching } \\
\text { and courses provided }\end{array}$ & 7.6 & 12.8 & 15.4 & 39.3 & 25.0 & 100.0 \\
\hline $\begin{array}{l}\text { The stf and } \\
\text { administration are easily } \\
\text { available to the students }\end{array}$ & 8.9 & 14.3 & 13.3 & 40.6 & 22.9 & 100.0 \\
\hline $\begin{array}{l}\text { The students are fully } \\
\text { informed of their } \\
\text { responsibilities }\end{array}$ & 5.5 & 9.6 & 14.6 & 45.8 & 24.5 & 100.0 \\
\hline $\begin{array}{l}\text { Details regarding the } \\
\text { location and availability of } \\
\text { all learning and physical } \\
\text { resources are communicated } \\
\text { to students. }\end{array}$ & 7.3 & 8.9 & 13.8 & 44.3 & 25.8 & 100.0 \\
\hline
\end{tabular}

The findings imply that leadership management was to a reasonable state embraced in enhancing the quality of the services by the universities thus a wide majority were satisfied with the various statement given. The findings agree with the argument by Ehigie and McAndrew (2005) who argued that through leadership management strategies which incorporate of involvement of the stakeholders in decision making, service quality is enhanced thus increasing satisfaction of the stakeholders. The findings however disagree with those of Brucaj (2014) who established that leadership in newly established universoties was poorly strategized thus causing unplactiness among the students and the staff and decreasing their satisfaction levels.

According to Sumaedi, Bakti and Metasari (2011) students' satisfaction levels is a matter of engaging them and making them feel as part of the institution. In this case, the students say that they are involved and thus their satisfaction levels are enhanced. Through leadership management, the organizations come up with strategies to involve stakeholders and make them satisfied with the environment available at their working places (Sheps, 2011). Similarly, students will require involvement and participation in the university matters for them to feel comfortable with the institutional services thus making them more satisfied and committed to the institution.

\subsubsection{Inferential Analysis of Ordered Probit Model on the Leadership Management and Students' Satisfaction}

\section{$\boldsymbol{H}_{A}:$ QMS leadership had significant positive influence on students' satisfaction in ISO 9001 certified universities in Kenya}

The study sought to find out the coefficients of determination and variation between leadership management and students' satisfaction. An ordered probit model analysis was used to determine the impact of leadership management on students' satisfaction in the ISO certified universities in Kenya. In the table 4.8 below, it demonstrates that leadership management has a significant relationship with students' satisfaction, and the p-value is 0.000 which is below 0.05 . This is therefore to mean that leadership management has a positive impact on students' satisfaction which means the better the leadership management the more the students' satisfaction. The findings show that leadership management has a statistically significant impact on the satisfaction of students in ISO certified universities in Kenya.

The model output compares with the findings by Purgailis and Zaksa (2012) who found that leadership is significantly related to satisfaction in that through involvement of the members and showing them that they are part of the strategies put in place to deliver services, they get more motivated and thus are satisfied. Enhancing communication and promoting information sharing play a very crucial role in enhancing satisfaction (Purgailis \& Zaksa (2012).

Table4. Ordered Probit Model on Leadership Management and Students'Satisfaction

\begin{tabular}{|l|l|l|l|l|ll|}
\hline Satisfaction & Coef. & Std. Err. & $\mathbf{Z}$ & $\mathbf{P}>\mathbf{Z}$ & [95\% Conf. Interval] \\
\hline Leadership & 1.054384 & .0676279 & 15.59 & 0.000 & .9218363 & 1.186933 \\
\hline Number of obs & 269 & \multicolumn{5}{|l|}{} \\
\hline Pseudo R $\mathbf{R}^{\mathbf{2}}$ & 0.0938 & & & \\
\hline
\end{tabular}




\section{CONCLUSION}

The study sought to establish role of quality management systems implementation on the students' satisfaction in ISO 9001:2008 certified universities in Kenya. From the findings, the study concluded thatleadership management contributes to satisfaction of the students among the universities. The study further concluded that the universities have embraced strategies to enhance proper leadership which made the students certified. The study also established that as much as most of the universities had embraced leadership management to enhance students' satisfaction, there were still some universities that had not embraced the strategy based on the fact that there were responses of dissatisfaction among the respondent as per the findings of the study.

\section{RECOMMENDATIONS}

The study recommended that the university management should adopt proper leadership strategies such as involvement of the students and seeking their views on the best direction to offer. The study recommends that the students should be put on note on the requirements and the progress that the university has put in place to enhance the quality of their services so as to make them feel part of the school community and get satisfied.

\section{Recommendations for further Study}

The study aimed at establishing the role of Leadership management under quality management systems implementation on the students' satisfaction in ISO 9001:2008 certified universities in Kenya. The study therefore focused on the ISO certified universities only thus there is need for a similar study to be conducted focusing on the universities and other higher learning institutions that are not ISO 9001:2008 certified.

The study was limited to universities which are learning institutions whereby the quality management systems may differ from other sectors. There is therefore an urge for a similar study to focus on other sectors such as the manufacturing and production sectors which are also as critical as the educational system in the economy.

\section{REFERENCES}

[1] AbaalKhail, M., \& Irani, Z. (2012). A Study of Influential Factors on Quality of Education. International Journal of Humanities and Applied Sciences (IJHAS), 94-97.

[2] Abdullah, M., Omar, M., \& Khan, B. Z. (2012). Measuring the Impact of ISO 900 Adoption on Business Performance: The Case of Malaysian SMEs. Global Conference on Operations and Supply Chain Management (pp. 200-212). Bandung: Global Research Agency.

[3] Aldrich, J.H. \& Nelson, F. D. (1984). Linear Probability, Logit, and Probit Models. Thousand Oaks, CA: SAGE Publications, Inc.

[4] Alharbi, M., \& Yusoff, R. Z. (2012). Leadership styles and their relationship with quality management practices in public hospitals in Saudi Arabia. International Journal of Economics and Management Sciences, 59-67.

[5] Al-Ibrahim, A. (2014). Quality Management and Its Role in Improving Service Quality in Public Sector. Journal of Business and Management Sciences, 123-147.

[6] Bohoris G.A. \& Vorria E.P., (2007). Leadership vs Management. Business Excellence/Performance Management view. Linkoping Electronic Conference Proceedings. Available at: http://www.ep.liu.se/ ecp/ 026/076/ecp0726076.pdf, [Retrieved 30 ${ }^{\text {th }}$ April 2017].

[7] Becket, N., \& Brookes, M. (2006). Evaluating quality management in university departments. Quality Assurance in Education, 123 - 142.

[8] Borooah, Vani K., (2002). Logit and Probit: Ordered and Multinomial Models. Thousand Oaks, CA: Sage Publications.

[9] Boyce, K., (2006). Using a Comprehensive Leadership Framework as a Scholarship and Teaching Tool. Journal of Leadership Education, 69-79.

[10] Bradley, D., Noonan, P., Nugent, H., \& Scales, B. (2008). Review of Australian higher education: Final report .Canberra: Department of Education, Employment and Workplace Relations.

[11] Brucaj, S. (2014). Promoting quality at newly established universities: new approaches to leadership management. European Journal of Research on Education,, 62-67 
[12] Cheng, Y. C. (1996). The Pursuit of School Effectiveness: Theory, Policy, and Research, The Hong Kong Institute of Educational Research, The Chinese University of Hong Kong, Hong Kong.

[13] Cheng, Y. C., \& Tam, W. M. (1997). Multi-models of quality in education. Quality Assurance in Education, 22-31.

[14] Cheng, Y. Y., Lyu, J., \& Lin, Y., (2004). Education Improvement through ISO 9000 Implementation: Experiences in Taiwan. International Journal in Engineering Education, 91-95.

[15] Cheng-Ling, T. Hasnah, H., Sofri, Y., Noornina, D., Yen Nee, G., \& Mohamed Azlan, A., (2011). Perception of Concerns about the Quality Management System Implementation on Its Levels of Use. International Journal of Business and Social Science, 201-208.

[16] Cronin, J. J., \& Taylor, S. A., (1992). Measuring service quality; a re-examination and extension. The Journal of Marketing, 55-68.

[17] Crosby, P.B. (1979). Quality Is Free: The Art of Making Quality Certain. New

[18] Cruz, W. B. da Souza, \& Melleiro, M. M., (2010). Assessment levels of the user's satisfaction in a private hospital. Revista da Escola de Enfermagem da USP, 147-153

[19] CUE. (2016, January 15). Status of Universities. Retrieved $8^{\text {th }}$ July, 2016 from http://cue.or.ke/ images/phocadownload/Accredited_Universities_Kenya_Nov2015.pdfDay, R.L. (1977), Extending the Concept of Customer Satisfaction, N.A, Howard.

[20] Davidson, R., \& MacKinnon J. G., (2004). Econometric Theory and Methods, Oxford University Press, USA.

[21] Deming, W. E. (1986) Out of the Crisis: Quality, Productivity, and Competitive

[22] Dinmukhamed, K., Kuatbek, K., Rima, Y., Botagoz, D., \& Alima, A. (2015). Determination of Quality Requirements in Tourism Management and Finance Departments of Akhmet Yassawi University by Kano Model. Mediterranean Journal of Social Sciences, 34-42.

[23] Duff, X. G. A., \& Hair, M. (2008). Service quality measurement in the Chinese corporate banking market. International Journal of Bank Marketing, 305-27.

[24] Duriau VJ, Reger RK, \& Pfaffer MD. (2007). A content analysis of the content analysis literature in organization studies: Research themes, data sources, and methodological refinements. Organizational Research Methods, 10, 5-34.

[25] Faganel, A., \& Macur, M., (2005). Competing through quality in higher education: the case of faculty of management Koper, Intellectual capital and knowledge management, in Proceedings of the 5th International Conference of the Faculty of Management, Koper.

[26] Farris, Paul W.; Neil T. Bendle; Phillip E. Pfeifer; David J. Reibstein (2010). Marketing Metrics: The Definitive Guide to Measuring Marketing Performance. Upper Saddle River, New Jersey: Pearson Education, Inc

[27] Feigenbaum, A. (1991). Total Quality Control (3rd ed.). New York: McGraw-

[28] Feinberg, M. (2006). An examination of authority in social classification systems. In Furner, Jonathan and Tennis, Joseph T. eds. Proceedings 17th Workshop of the American Society for Information Science and Technology Special Interest Group in Classification Research 17, Austin, Texas. Available list. sir.arizona.edu/1783/01/feinberg.pdf

[29] Firdaus, A., (2006). Measuring service quality in higher education: three instruments compared. International Journal of Research \& Method in Education, 71-89.

[30] French, E., Summers, J., Kinash, S., Lawson, R., Taylor, T., Herbert, J., \& Hall, C., (2014). The practice of quality in assuring learning in higher education. Quality in Higher Education, 24-43.

[31] Garwe, E. C., (2015). The effect of institutional leadership on quality of higher education provision. Research in Higher Education Journal, 1-10.

[32] George, D., \& Mallery, P., (2003). SPSS for Windows step by step: A simple guide and reference. 11.0 update (4th ed.). Boston: Allyn \& Bacon.

[33] Gilmore, A., \& McMullan, R., (2009). "Scales in services marketing research: a critique and way forward", European Journal of Marketing, 640-51.

[34] Gomez, L. (2017). Comparative analysis of the educational management strategies between public and private university in Mexico. Journal Plus Education, 21-40.

[35] Jankowicz, A. D., (2005). Business Research Projects. London: International Thomson Business Press $4^{\text {th }}$ edition.

[36] Johanson, G. A., \& Brooks, G. P. (2010). Initial Scale Development: Sample Size for Pilot Studies. Educational and Psychological Measurement, 394-400.

[37] Juran, M., and Godfrey, A. (1998). Juran's quality handbook (5th ed.). Washington, DC: McGraw-Hill Companies, Inc. 
[38] Kagumba, A. M., \& Gongera, G. E. (2013). Quality Assurance Strategy on Organizational Performance: Case of Kenyatta University. European Journal of Business and Management, 265-270.

[39] Kalthom, A., Muhammad, T. J., \& Noorhazilah, A. M. (2012). A Structural Equation Modelling Approach to Validate the Dimensions of SERVPERF in Airline Industry of Malaysia. International Journal of Engineering and Management Sciences (IJEMS), 134-141.

[40] Kasumawati, L., Kamaruddin, N. M., Razali, T. N., Ching Lee, T. D., Azim, A., Masri, T., \& Othman, A., (2010). The Implementation of Quality Management System (QMS) in Teaching, Learning and Assessment in Faculty of Engineering, Universiti Malaysia Sarawak. The 3rd Regional Conference on Engineering Education and Research in Higher Education (pp. 1-5). Kuching: RCEE \& RHEd.

[41] Kaziliunas, A., (2010). The Implementation of Quality Management Systems in Service Organizations. Public policy and administration, 71-82.

[42] KEBS. (2015, June 13). Certified Firms: ISO 9001:2008 Quality Management Systems. Retrieved from KEBS: http://kebs.org/index.php?opt=certification\&view=qms_firms

[43] Kemenade, E. V., Pupius, M., \& Hardjono, T. W. (2008). More value to defining quality. Quality in Higher Education, 175-185.

[44] Ling, K. C., Piew, T. H., \& Chai, L. T. (2010). The Impact of Resource Input Model of Education Quality on the Overall Students' Perceived Service Quality. Canadian Social Science, 125-144.

[45] Long, J. S., \& Freese, J. (2014). Regression Models for Categorical Dependent Variables Using Stata. College Station: Stata Press.

[46] Loshini, T., \& Sabri, A. (2014). Structural Equation Modelling: Confirmatory Factor Analysis to Construct Measurement Model \& Mediator Check among Formed Factors. Mathematical Theory and Modelling, 7182.

[47] Lovelock, C., \& Wirtz, J., (2011). Services Marketing. New Jersey: Pearson Education.

[48] Lushi, I., Mane, A., Kapaj, I., \& Keco, R. (2016). “A Literature Review on ISO 9001 Standard,” European Journal of Business, Economics and Accountancy, 4(2), 81-85.

[49] Maslowski, R., Doolaard, S., \& Bosker, R. J. (2008). Much more than the effective classroom: a lifetime of research, evaluation, improvement, and dissemination. School Effectiveness and School Improvement, 353-363.

[50] Meirovich, G., \& Bahnan, N., (2008). Relationship between the components of product/service quality and the customers' emotions and satisfaction. Journal of Industrial Engineering and Management, 185-208.

[51] Mekic, E., \& Goksu, A., (2014). Implementation of ISO 9001:2008 \& Standards for Accreditation at Private University in Bosnia And Herzegovina. European Researcher, 947-961.

[52] Michalska-Ćwiek, J., (2009). The quality management system in education - implementation and certification. Journal of Achievements in Materials and Manufacturing Engineering, , 733-750.

[53] Naik, C. K., Gantasala, S. B., \& Prabhakar, G. V. (2010). Service Quality (Servqual) and its Effect on Customer Satisfaction in Retailing. European Journal of Social Sciences, 231-243.

[54] Neyestani, B. (2017). Principles and Contributions of Total Quality Mangement (TQM) Gurus on Business Quality Improvement. The Munich Personal RePEc Archive (MPRA), 1-17.

[55] Neyestani, B., \& Juanzon, J. B. P. (2016). "Developing an Appropriate Performance Measurement Framework for Total Quality Management (TQM) in Construction and Other Industries. IRA-International Journal of Technology \&Engineering, 32-44.

[56] Ojiambo, P. O., (2009). Quality of Education and its Role in National Development: A Case study of Kenya's Educational Reforms. Kenya Studies Review, 133-149.

[57] Olugbenga, A. T. (2010). Private Universities in Nigeria - the Challenges Ahead. American Journal of Scientific Research, 15-24.

[58] Pitman, T., (2014). Reinterpreting higher education quality in response to policies of mass education:the Australian experience. Quality in Higher Education, 1-16.

[59] Safari, A., \& Sabouri, R., (2014). Studying the relationship between leadership styles and applying Principles total quality management. Indian journal of Scientific Research (IJSR), 391-299.

[60] Saizarbitoria, I. H. (2006). How Quality Management Models Influence Company Results- Conclusions of an Empirical Study Based on the Delphi Method. Total Quality Management, 775-794.

[61] Tari, J. J., (2005). Components of successful total quality management. The TQM Magazine, 182-194.

[62] Thompson-Whiteside, S. (2013). Assessing acadmeic standards in Australian higher education. In S. Marginson (Ed.), Tertiary education policy in Australia, 39-58.

[63] Venkatraman, S., (2007). A framework for implementing TQM in higher education programs. Quality Assurance in Education, 92-112. 
[64] Vlasic, S., Vale, S., \& Puhar, D. K., (2009). Quality Management in Education. Interdisciplinary Management Research, 565-573.

[65] Zafiropoulos, C., \& Vrana, V., (2008). Service quality assessment in a Greek higher education institute. Journal of Business Economics and Management, 33-45.

[66] Zikmund, W. G. (2010). Business Research Methods.Florida: The Dryden Press

Citation: Hilary Kipchirchir Kandie, Wario Guyo (PhD), Thomas A. Senaji (PhD). "Effect of Leadership Management on Students' Satisfaction in ISO 9001: 2008 Certified Universities in Kenya "International Journal of Managerial Studies and Research (IJMSR), vol 6, no. 2, 2018, pp. 29-43. doi:http://dx.doi.org/10.20431/2349-0349.0602004.

Copyright: (C) 2018 Authors. This is an open-access article distributed under the terms of the Creative Commons Attribution License, which permits unrestricted use, distribution, and reproduction in any medium, provided the original author and source are credited. 